\title{
Kitchen waste compost increases lettuce growth and shows residual effect on soil fertility
}

\author{
Alessandra Monteiro de Paula ${ }^{1 *}{ }^{\oplus}$, Jhon Kenedy Moura Chagas ${ }^{1} \oplus$, Ana Cláudia Oliveira Sérvulo ${ }^{1}$,

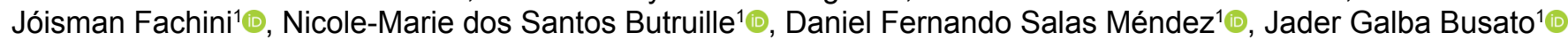 \\ 1 Universidade de Brasília, Faculdade de Agronomia e Medicina Veterinária, Brasilia, DF, Brasil. E-mail: alessandramp@unb.br; kenedymc@gmail.com; anaclaudiaoservulo@hotmail.com; \\ joismanfachini@hotmail.com; nicbut1606@gmail.com; salas.daf.agro@gmail.com; jaderbusato@unb.br
}

ABSTRACT: Composting is an important tool for transforming organic waste into useful products for agriculture. However, the characterization of the compost and its capacity to stimulate crop growth are necessary to ensure sanitary quality and process efficiency. In this study, the objectives were characterize and evaluate a kitchen waste compost produced in static piles as a stimulant to lettuce growth. The residual effect of compost on soil fertility was also studied. A randomized block design was used, with 3 replications of compost doses equivalent to $0,30,60$ and $90 \mathrm{t} \mathrm{ha}^{-1}$. The compost presented chemical characteristics that allow their agricultural use according to Brazilian regulations, but a high electrical conductivity (EC) value was detected. The absence of $E$. coli indicated that the process was efficient to guarantee the elimination of the pathogenic contaminant. Although compost has reduced net $\mathrm{CO}_{2}$ assimilation, stomatal conductance and leaf transpiration in plants, consistent increases in shoot and root dry mass, as well as in shoot projection were noticed, with the dose of $90 \mathrm{t} \mathrm{ha}^{-1}$. Residual effect in soil fertility was also confirmed. The kitchen waste compost obtained from static piles is a safe product that enables the recycling of nutrients, spurring the development of lettuce and resulting in a residual effect on soil fertility.

Key words: circular economy; recycling; sanitary quality; vegetable production; waste management

\section{Composto de resíduos de cozinha aumenta o crescimento de alface e apresenta efeito residual sobre a fertilidade do solo}

RESUMO: A compostagem é uma ferramenta importante para transformar resíduos orgânicos em produtos úteis para a agricultura. Porém, a caracterização do composto e sua capacidade de estimular o crescimento das lavouras são necessárias para garantir a qualidade sanitária e a eficiência do processo. Neste estudo, os objetivos foram caracterizar e avaliar um composto de resíduos de cozinha produzido em pilhas estáticas como estimulante do crescimento da alface. $O$ efeito residual do composto na fertilidade do solo também foi estudado. $O$ delineamento experimental foi em blocos casualizados, com 3 repetições de doses de composto equivalentes a 0, 30, 60 e $90 \mathrm{t} \mathrm{ha}^{-1}$. O composto apresentou características químicas que permitem seu aproveitamento agrícola de acordo com a regulamentação brasileira, mas foi detectado um alto valor de condutividade elétrica (CE). A ausência de $E$. coli indicou que o processo foi eficiente para garantir a eliminação do contaminante patogênico. Embora o composto tenha reduzido a assimilação líquida de $\mathrm{CO}_{2}$, a condutância estomática e a transpiração foliar nas plantas, aumentos consistentes na massa seca da parte aérea e da raiz, bem como na projeção da parte aérea foram observados, com a dose de 90 t ha-1 ${ }^{-1} 0$ efeito residual na fertilidade do solo também foi confirmado. 0 composto de resíduos de cozinha obtido a partir de pilhas estáticas é um produto seguro que possibilita a reciclagem de nutrientes, estimulando o desenvolvimento da alface e resultando em um efeito residual na fertilidade do solo.

Palavras-chave: economia circular; reciclagem; qualidade sanitaria; produção vegetal; manejo de resíduos

\footnotetext{
*Alessandra Monteiro de Paula - E-mail: alessandramp@unb.br (Corresponding author)

Associate Editor: Mário de Andrade Lira Júnior
} 


\section{Introduction}

Waste generation is inherent to human activity, but production grew to worrying levels in recent decades. Over three million tons of waste are produced daily around the world, and this amount may increase between 38 and $67 \%$ by 2025 (Hoornweg \& Bhada-Tata, 2012). Brazil produces more than 78 million tons of urban solid waste (USW) annually, of which $51 \%$ has organic origin (ABRELPE, 2017). Kitchen organic waste is a type of USW produced from households and restaurants, and its disposal in unplanned areas without any treatment contributes to public health problems and environmental contamination (Han et al., 2016). Incineration would be a more suitable destination, but the moisture of kitchen waste (Sakarika et al., 2019) makes this strategy not efficient. Another possibility is disposal in landfills, but they have high operating costs and makes recycling materials impossible.

To circumvent these barriers, many countries have set goals and policies to reduce the volume of USW sent to landfills by implementing small and medium-scale biological treatment systems, such as composting. Composting is an effective tool to treat kitchen organic waste, which has a highly positive impact on USW management plans (Arrigoni et al., 2018). The Brazilian National Policy on Solid Waste (Federal law number 12,305/2010) associates the idea of a circular economy and recycling, increasing the number of private companies that offer composting services. These start-ups collect the material in a door-to-door process and transport it to a planned area, where it is transformed into organic fertilizer using mainly composting systems of static piles. When conducted properly, the process reduces the waste volume due to $\mathrm{CO}_{2}$ loss and decrease the levels of pathogenic microorganisms, resulting in a safe fertilizer that meets the quality standards for agriculture (Barrena et al., 2014; Manyapu et al., 2018; Sakarika et al., 2019).

Similarly, to waste generation, the demand for fertilizers has grown in the last few years. The global consumption of the three main fertilizer nutrients: nitrogen $(N)$, phosphorus (expressed as $\mathrm{P}_{2} \mathrm{O}_{5}$ ) and potassium $\left(\mathrm{K}_{2} \mathrm{O}\right)$, was estimated to be more than 186 million tonnes in 2016, with an annual growth forecast up to $2.4 \%$ by 2020 (FAO, 2017). The sustainability of the production of fertilizers using mineral sources is recurrently criticized, and new possibilities have been sought. Thus, recycling plant nutrients from organic waste through composting is part of a strategy to decrease the global demand for mineral fertilizers. Since soil-applied organic composts can have an immediate or residual effect on nutrient levels, their application can improve fertility indicators in various crops. Lastly, organic composts have a variety of components, which improve plant growth by mechanisms associated with hormonal-like action, disease and pest control and attenuation of abiotic stress (Stewart-Wade, 2020).

Therefore, the objectives of this study were (i) to characterize a kitchen waste compost produced in static piles in the Federal District of Brazil; (ii) to evaluate its effectiveness as a plant growth stimulant for lettuce and (iii) investigate the existence of residual effects of the compost on the soil fertility indicators.

\section{Materials and Methods}

\section{Compost production}

The compost was produced by the Compostar Project ${ }^{\mathrm{TM}}$, a company that collects, transports and process kitchen organic waste from homes and restaurants in Brasília, Federal District of Brazil $\left(15^{\circ} 41^{\prime} 0.5^{\prime \prime} \mathrm{S}, 47^{\circ} 51^{\prime} 44.6^{\prime \prime} \mathrm{W}\right)$. The feedstock used in the composting process included pre- and post-consumer organic residues, such as leftover fruit, vegetables, meat, dairy and fats. Grass pruning was used to cover the top and side of the piles to avoid the attraction of insects and the release of odours. The composting was performed in a static windrow system with $10 \mathrm{~m}$ in length, $1.8 \mathrm{~m}$ in height and $1.2 \mathrm{~m}$ in width, with approximately 8 tonnes of waste. A soil sealing system was used to collect the leachate, which was recirculated in the piles using an electric pump.

\section{Compost characterization}

After 150 days of composting, the material was sampled according to the NBR 10.007 standard procedure (ABNT, 2004) and the analysis performed according to Official analytical methods for mineral, organic, organomineral and corrective fertilizers Guide (Brasil, 2014a). The samples ( $n=4$, each one formed by the mixture of 17 subsamples, obtained at the base, middle and top of the piles) were homogenized, air-dried, ground in a Willey knife mill (SL31, Solab Científico) and sieved $0.5 \mathrm{~mm}$. After this, $\mathrm{pH}$ value was determined by shaking the sample in $0.01 \mathrm{~mol} \mathrm{~L}^{-1} \mathrm{CaCl}_{2}$ (ratio of $1: 5, \mathrm{w}: \mathrm{v}$ ), using a $\mathrm{pH}$-meter equipped with a glass electrode (Tec 5 , Tecnal). The electrical conductivity (EC) was measured in the same extract using a digital conductivity meter (9468 M, Quimis). Total organic carbon (TOC) was estimated by the modified Walkley-Black procedure and total nitrogen content (TNC), using the Kjeldahl method. The cation-exchange capacity (CEC) was determined after the saturation of the exchange sites with $0.5 \mathrm{~mol} \mathrm{~L}^{-1} \mathrm{HCl}$ solution and titration with the $\mathrm{CH}_{3} \mathrm{COOH}$ formed. The total $\mathrm{P}$ was estimated by colorimetry at $660 \mathrm{~nm}$ (U-2910, Hitashi), after digesting $0.5 \mathrm{~g}$ of the compost with concentrated $\mathrm{H}_{2} \mathrm{SO}_{4}$ and $\mathrm{H}_{2} \mathrm{O}_{2}$, using the ascorbic acid/molybdate method. Total $\mathrm{K}$, $\mathrm{Ca}, \mathrm{Mg}, \mathrm{Fe}, \mathrm{Mn}, \mathrm{Zn}, \mathrm{Cr}$ and $\mathrm{Cu}$ were determined by inductively coupled plasma optical emission spectrometry (ICPE-9000, Shimadzu), after digesting the samples with $\mathrm{HNO}_{3}$ and $\mathrm{HClO}_{4}$ in a microwave digestion system (CEM 5, Mars).

\section{Escherichia coli test}

E. coli was counted in the compost using Colilert QuantiTray $^{\circledR}$ (INDEXX Inc., Westbrook) most probable number method following the manufacturer's instructions. After incubation at $37^{\circ} \mathrm{C}$ for 24 hours, wells fluorescing "blue" under ultraviolet light were recorded as positive for $E$. coli. Positive (sewage effluent) and negative (sterile water) controls were used in testing. 
Lettuce growth, photosynthesis rate and leaf gas parameters

Compost doses equivalent to $0,30,60$ and $90 \mathrm{t} \mathrm{ha}^{-1}$ were incorporated at $0-0.20 \mathrm{~m}$ deep in a Red-Yellow Latosol (Embrapa, 2013) and lettuce seedlings (Lactuca sativa L., crespa grand rapids) of approximately 10 days, produced using commercial substrate (Biplan Plus, Hobby Verde), were transplanted to cultivation beds in a spacing of $0.3 \times 0.3 \mathrm{~m}$. The plots $(n=3)$ consisted of $1.0 \times 1.0 \mathrm{~m}$, with a total of 9 plants per plot. Each replicate was obtained considering the average from the 9 plants. After 41 days of growing, the shoot projection was determined after digital image acquisition, processed using the program Image ${ }^{\mathrm{TM}}$. The net $\mathrm{CO}_{2}$ assimilation, stomatal conductance, internal $\mathrm{CO}_{2}$ concentration and leaf transpiration were determined using a portable photosynthesis system (LI 6400 XT, Licor), with a standard $6 \mathrm{~cm}^{2}$ leaf chamber. The equipment was calibrated and adjusted to use artificial light of $1000 \mu \mathrm{mol}$ of active photons $\mathrm{m}^{-2} \mathrm{~s}^{-1}, \mathrm{CO}_{2}$ concentration at $400 \mu \mathrm{mol} \mathrm{mol} \mathrm{m}^{-1}$ and air flow rate at $500 \mu \mathrm{mol} \mathrm{s}^{-1}$. The average temperature in the leaf chamber was $28.0 \pm 1.6{ }^{\circ} \mathrm{C}$ and relative humidity was $50.2 \pm$ $4.0 \%$. The measurements were taken from fully developed leaves, located in the middle part of the plant, between 10 and $12 \mathrm{am}$. The plants were harvest and separated in shoot or root parts, dried in forced-air circulation oven at a temperature of $65{ }^{\circ} \mathrm{C}$ for 72 hours, until constant weight was achieved (Ethiktechnology, 420 TD), then they were weighed to determine the shoot and root dry mass in analytical balance (Gehaka, AG 200).

\section{Residual effect on soil fertility}

After harvesting, soil samples were collected from the 0-0.20 $\mathrm{m}$ depth to verify the residual effect of the compost on soil fertility. For this, ten subsamples were collected from each plot to obtain a composite sample. They were air-dried, sieved through a 2-mm screen and analysed according to standards established by Embrapa (2011). Briefly, the pH was determined using a $\mathrm{pH}$-meter equipped with a glass electrode (Tec 5, Tecnal), in a soil-water ratio of 1:2.5 (w:v). Electrical conductivity (EC) was measured in the same extract using a digital conductivity electrode (9468 M, Quimis). Phosphorus and $\mathrm{K}$ were extracted using a Mehlich-1 solution, then $\mathrm{P}$ was determined by colorimetry at $660 \mathrm{~nm}$ (U-2910, Hitashi), using the ascorbic acid/molybdate method, and $\mathrm{K}$ was measured by flame photometry (B462, Micronal). Calcium plus magnesium $(\mathrm{Ca}+\mathrm{Mg})$ and exchangeable aluminum (Al) were extracted with $1.0 \mathrm{~mol} \mathrm{~L}^{-1} \mathrm{KCl}$ at pH 5.5 and quantified by titration with 0.0125 mol L $^{-1}$ EDTANa $_{2}$ and $0.025 \mathrm{~mol} \mathrm{~L}^{-1} \mathrm{NaOH}$, respectively. Total acidity $(\mathrm{H}+\mathrm{Al})$ was extracted using $0.5 \mathrm{~mol} \mathrm{~L}^{-1} \mathrm{Ca}\left(\mathrm{CH}_{3} \mathrm{COO}\right)_{2}$ $2 \mathrm{H}_{2} \mathrm{O}$ at $\mathrm{pH} 7.0$ and quantified by titration with $0.025 \mathrm{~mol}$ $\mathrm{L}^{-1} \mathrm{NaOH}$. Total organic carbon (TOC) was determined by the modified Walkley-Black procedures.

\section{Statistical analysis}

The data was submitted to the Shapiro-Wilk normality and variance homogeneity tests. The shoot projection, net $\mathrm{CO}_{2}$ assimilation, stomatal conductance, internal $\mathrm{CO}_{2}$ concentration and leaf transpiration, shoot and root dry mass and soil fertility indicators were evaluated by regression analysis, and for those that obtained no regression adjustment, a test of means (LSD test, $p<0.05$ ) was applied. The regression models were chosen according to the significance and the highest $R^{2}$ value. To explore and find groupings in soil fertility indicators and compost doses, a principal component analysis (PCA) was performed to standardized data sets. Compost chemical characterization and $E$. coli were descriptively analysed.

\section{Results and Discussion}

\section{Chemical characterization and $E$. coli test}

Table 1 presents the chemical characteristics and E. coli enumeration of the compost and compare it with the results of Manyapu et al. (2018), Sakarika et al. (2019) and Yang et al. (2019), which also used kitchen waste to obtain compost. Results were also confronted with the limits established by Brazilian regulations (Brasil, 2006; 2009; 2014b). The $\mathrm{pH}$ value of 8.0 is within the limits recommended for use in agriculture $(\geq 6.0)$ and was higher than that of the other composts used for comparison, except for the one presented by Sakarika et al. (2019). The relatively high $\mathrm{pH}$ in the compost was probably due to the presence of meat and fats in the feedstock, which served as a protein source for microorganisms.

The EC value of $5.0 \mathrm{mS} \mathrm{cm}^{-1}$ (Table 1) was also higher than the ones achieved by other studies. The high EC values may be related to the origin of the waste processed at the facilities, such as kitchen waste, which contains salts used in food preparation and preservation. Brazilian regulations do not limit the agricultural use of composts based on EC values, but is important to mention that the direct use of composts with $\mathrm{EC}>4.0 \mathrm{mS} \mathrm{cm} \mathrm{cm}^{-1}$ may result in phytotoxicity, affecting seed germination and negatively influence the plant growth (SilesCastellano et al., 2020).

Total organic carbon was slightly lower (319.9 $\mathrm{mg} \mathrm{g}^{-1}$ ) than the ones found in the studies of Yang et al. (2019) and Manyapu et al. (2019), but much higher than that of Sakarika et al. (2019) (Table 1). On the other hand, the content of TNC (22.3 $\left.\mathrm{mg} \mathrm{g}^{-1}\right)$ was within the range observed in the other studies, which varied from 8.5 to $23.0 \mathrm{mg} \mathrm{g}^{-1}$. Both TOC and TNC determined in this study were higher than the minimum required by the Brazilian regulation (Brasil, 2009), and the relation between them resulted in a $\mathrm{C} / \mathrm{N}$ ratio of $14.3 / 1$, considered safe for agricultural use and common in stable composts (C/N ratio < 20.0; Brasil 2009).

Compost presented CEC of $119.0 \mathrm{cmol}_{\mathrm{c}} \mathrm{kg}^{-1}$ (Table 1) and, similarly to EC, there is not a reference value for $\mathrm{CEC}$ in Brazilian regulations. The CEC in the compost is due to the presence of carboxyl, carbonyl, phenolic hydroxyl, ether and hydroxyl present in the compost (Busato et al., 2012). The observed value for CEC in the compost is higher when compared with the natural CEC in the soils from the Cerrado biome (Lopes \& Guilherme, 2016).

The contents of $\mathrm{P}$ and $\mathrm{K}$ were 31.0 and $3.2 \mathrm{~g} \mathrm{~kg}^{-1}$, respectively, which were higher than the one showed by Sakarika et al. 
Table 1. Chemical characterization and E. coli enumeration of a kitchen waste compost produce in static piles, in Brasília, Brazil.

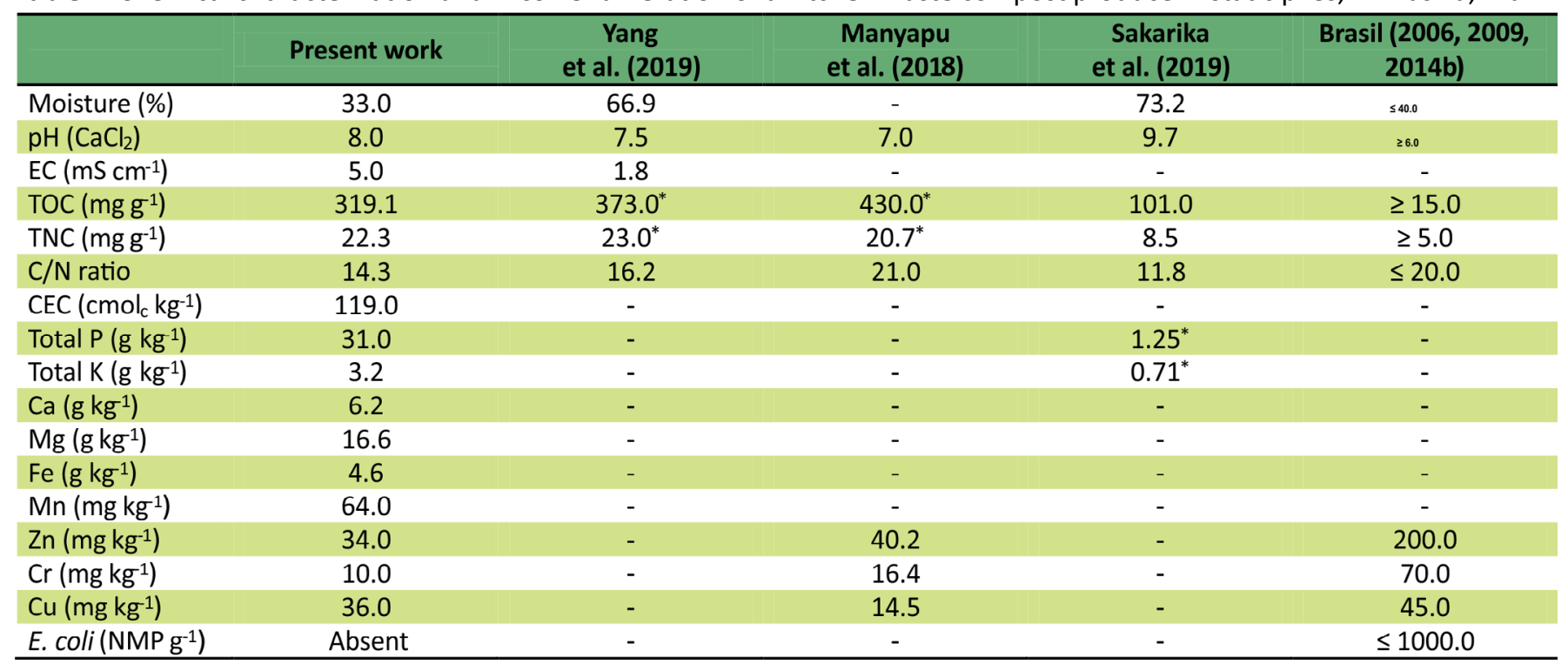

* Original values presented in percentage (\%). EC: electrical conductivity; TOC: total organic carbon; TNC: total nitrogen content; CEC: cation exchange capacity.

(2019). The contents of $\mathrm{Zn}\left(34.0 \mathrm{mg} \mathrm{kg}^{-1}\right), \mathrm{Cr}\left(10.0 \mathrm{mg} \mathrm{kg}^{-1}\right)$ and $\mathrm{Cu}\left(36.0 \mathrm{mg} \mathrm{kg}^{-1}\right)$ are below the limit established by Brazilian regulations (Brasil, 2014b).

Kitchen waste compost showed absence of $E$. coli bacteria (Table 1) when analysed by the most probable number method. There is a growing public concern with regards to the risk of food-waste-borne pathogens reaching crop lands when compost is used as soil fertilizer. The presence of $E$. coli indicates, among others, faecal contamination, and presence of pathogenic microorganisms. During the composting process, a combination of time and temperature in the piles is required to eliminate these microorganisms, resulting in compost sanitation (Barrena et al., 2014). The absence of E. coli indicates that the process occurred in sufficient temperature and time, resulting in a safe material to be used in agriculture.

\section{Lettuce growth}

Significant increases for shoot and root dry mass and for shoot projection in response to the kitchen waste compost were observed (Figure 1). For shoot dry mass (Figure 1A), the values varied from $4.2 \mathrm{~g} \mathrm{plant}^{-1}$, in the dose of $30 \mathrm{t} \mathrm{ha}^{-1}$, to $6.1 \mathrm{~g} \mathrm{plant}^{-1}$, with $90 \mathrm{t} \mathrm{ha}^{-1}$. Plants grown without compost addition showed a much lower value of $1.0 \mathrm{~g} \mathrm{plant}^{-1}$. The biggest increase rate was verified with the application of up to $30 \mathrm{t} \mathrm{ha}^{-1}$, in an average $0.11 \mathrm{~g} \mathrm{plant}^{-1}$ for each ton of added compost. The root dry mass increased from $0.18 \mathrm{~g}$ plant $^{-1}$, without compost addition, to $0.60,0.85$ and $1.02 \mathrm{~g}$ plant $^{-1}$ with the addition of 30,60 and $90 \mathrm{t} \mathrm{ha}^{-1}$, respectively (Figure 1B). This represented rises in the order of 233.3, 372.2 and $466.7 \%$ due the compost addition. The shoot projection area without compost was of $30.1 \mathrm{~cm}^{2}$ and reached 290.1, 330.4 and $400.7 \mathrm{~cm}^{2}$, with the doses of 30,60 and $90 \mathrm{t} \mathrm{ha}^{-1}$, respectively, representing significant increase of $863.8,997.7$ and $1231.2 \%$ (Figure $1 \mathrm{C}$ ).

Several benefits justify the greater plant growth as a result of adding organic composts to agricultural soils. Mineralization of nitrogen, phosphorus and sulphur from organic fertilisers derived from waste recycling increase the availability of

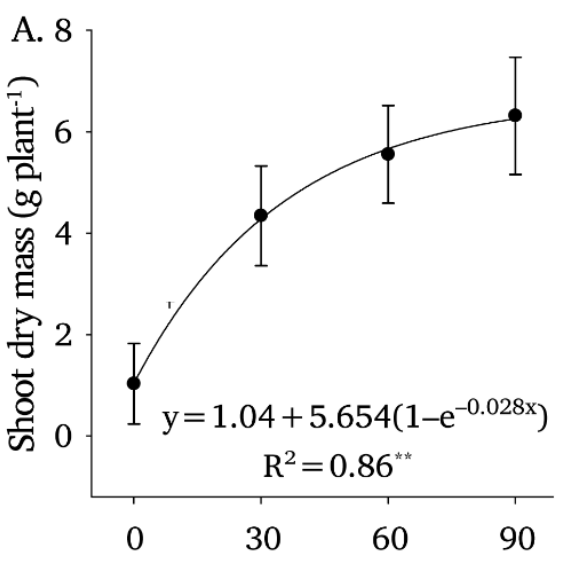

Bars represents standard deviation. * $p<0.05 ;{ }^{* *}$ : $p<0.001$.
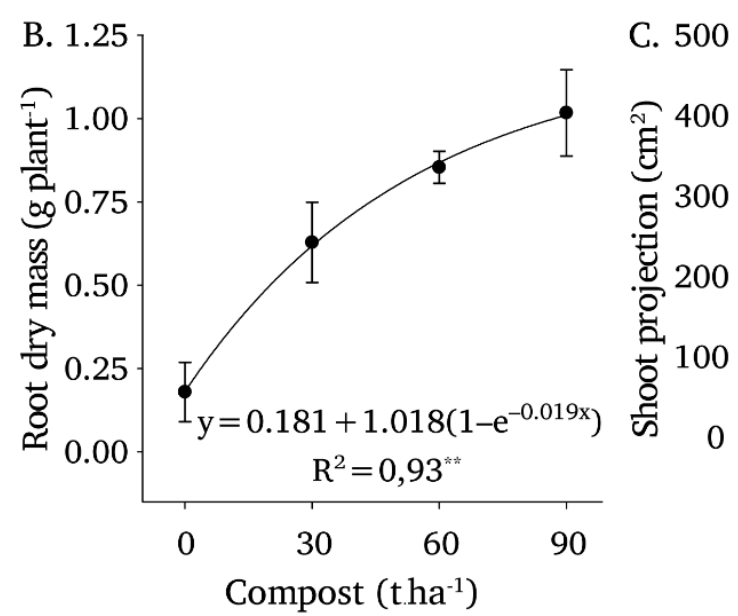

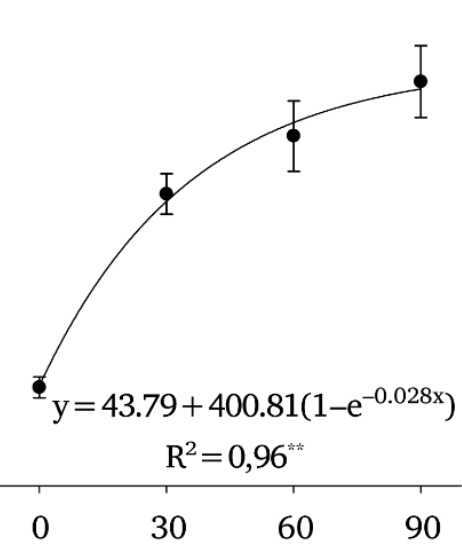

Figure 1. Shoot dry mass (A), root dry mass (B) and shoot projection area (C) of lettuce cultivated with different doses of kitchen waste compost. 
these nutrients and when associated with management practices, such as green manure, might ensure a satisfactory yield response and preservation of soil fertility (Testani et al., 2019). The boost in enzymatic activities, microorganism communities and plant hormones also contribute to a higher plant growth. Organic composts have a large amount of humic substances, which triggers an alteration in the plant gene expression responsible for different physiological processes of the plant (e.g., Krebs cycle, metabolisms and photosynthesis) (Roomi et al., 2018). These substances enhance the activity of the enzymes responsible for $\mathrm{N}$ assimilation, modulate the calcium-dependent protein kinase and stimulate membrane $\mathrm{H}^{+}$-ATPase, a protein directly responsible for the acquisition of nutrients by plants (Roomi et al., 2018).

The addition of compost on soils also plays an indirect action of soil microorganisms influences plant growth due to the higher availability of growth substances, such as vitamins, phytohormones and pathogen controllers (Corato et al., 2018). Finally, the Cerrado soils are also naturally poor in cations such as $\mathrm{K}, \mathrm{Ca}$, and $\mathrm{Mg}$, as well as in available $\mathrm{P}$ (Lopes \& Guilherme, 2016) and, to overcome these limitations, limestone (for $\mathrm{Ca}$ and $\mathrm{Mg}$ ), acidulated rock phosphate and soluble potash are added to soils in large amounts. There is no doubt that these products benefit plant growth, but their non-renewable origin concerns contemporary society. Kitchen organic waste contains plant nutrients in its composition and recycling them could alleviate the pressure on mineral deposits used for the production of industrial fertilizers, extending their lifespan.
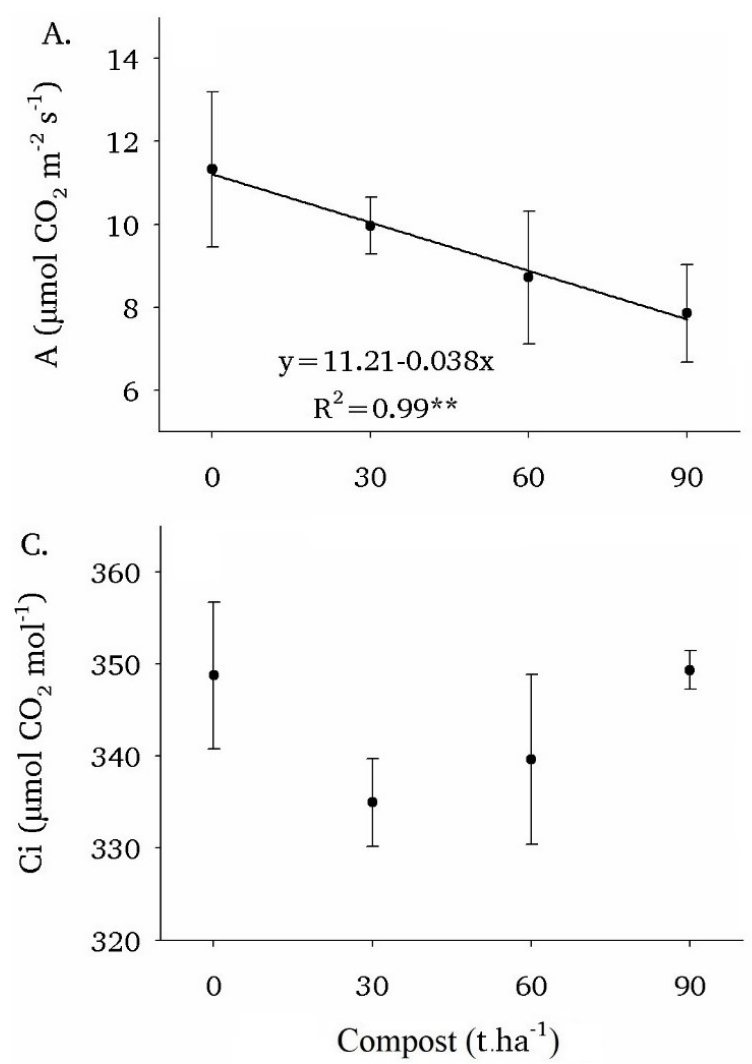

In this study, it was observed that each ton of kitchen waste compost recycles, in kilograms (kg): 31 of total P, 3.2 of total $\mathrm{K}, 6.2 \mathrm{~kg}$ of $\mathrm{Ca}, 16.6$ of $\mathrm{Mg}, 4.6$ of $\mathrm{Fe}$, and $64 \mathrm{~g}$ of $\mathrm{Mn}, 34 \mathrm{~g}$ of $\mathrm{Zn}$ and $36 \mathrm{~g}$ of $\mathrm{Cu}$. Although these concentrations are lower than industrial fertilizers', harnessing the nutrients present in this type of residue represents an important step for the development of a more sustainable agriculture.

Net $\mathrm{CO}_{2}$ assimilation, stomatal conductance, internal $\mathrm{CO}_{2}$ concentration and leaf transpiration

Linear decrease in the net $\mathrm{CO}_{2}$ assimilation rate was observed with increasing doses of the compost (Figure 2A). It was not possible to determine significant mathematical models for stomatal conductance, the internal concentration of $\mathrm{CO}_{2}$ and leaf transpiration. However, the LSD test showed that all compost doses resulted in reduction of the stomatal conductance compared to the treatment without the addition of compost (Figure 2B). Comparing the average of the doses 30,60 and $90 \mathrm{t} \mathrm{ha}^{-1}$ and the treatment without compost, the reduction was in the order of $53.5 \%$. The internal concentration of $\mathrm{CO}_{2}$ (Figure 2C) was not affected by the compost. On the other hand, similar to the stomatal conductance, leaf transpiration in the plants grown with the addition of compost (average for the three doses) decreased in about 30\%, when compared to the plants without the compost.

Combined, the nutritional and the physiological effects, as well as the modulation of microbial activity and physical conditions of the soil due to the addition of the kitchen waste
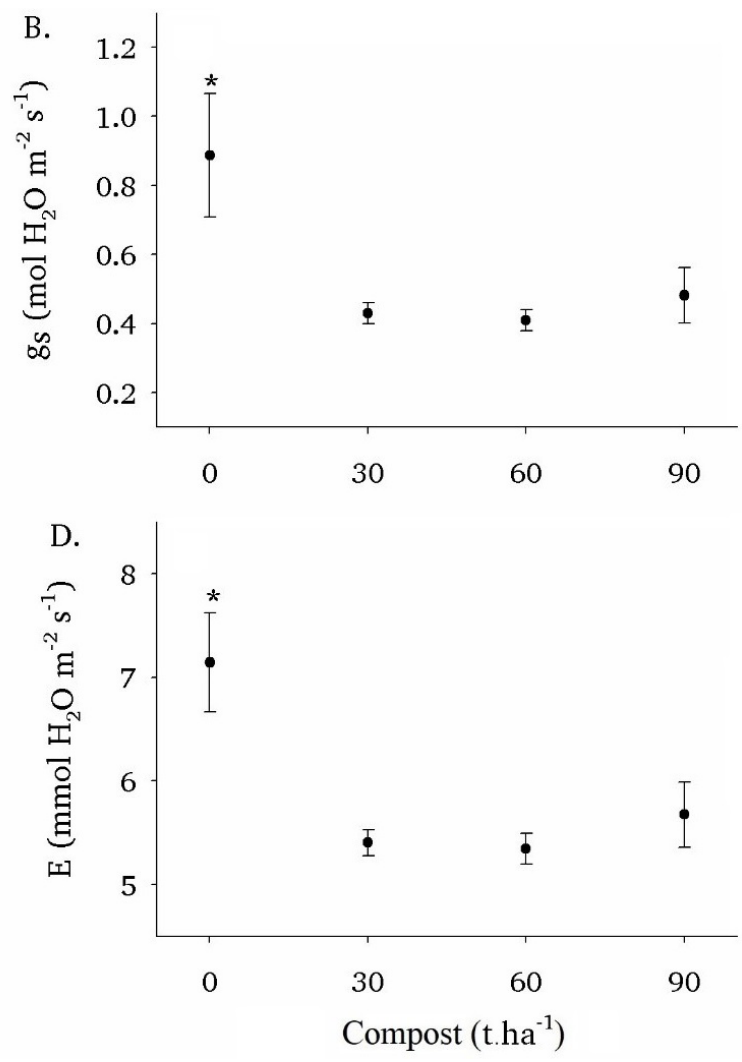

Bars represents standard deviation. ${ }^{*}: \mathrm{p}<0.05 ;{ }^{* *}: \mathrm{p}<0.001$.

Figure 2. Net $\mathrm{CO}_{2}$ assimilation rate "A" (A), stomatal conductance "gs" (B), internal $\mathrm{CO}_{2}$ concentration "Ci" (C) and leaf transpiration " $E$ " (D) in lettuce plants grown under different doses of kitchen waste compost. 
compost (Stewart-Wade, 2020), enhanced lettuce growth. Nevertheless, plants under compost addition have decreased the net $\mathrm{CO}_{2}$ assimilation rate, stomatal conductance and leaf transpiration (Figure 2A, B and D). Plants subjected to stress conditions respond by producing compounds that can lead to stomatal closure, reducing water loss, however, this condition decrease leaf $\mathrm{CO}_{2}$ concentration and photosynthesis (Park et al., 2021). The release of salts through mineralization of organic composts can result in plant stress due to an osmotic imbalance, which can reduce water absorption, stomatal conductance and net $\mathrm{CO}_{2}$ assimilation (Marenco et al., 2014). The kitchen waste compost showed a high value for EC, which increased the soil EC. This occurrence could be responsible for the reduction in photosynthetic and gas exchange parameters.

In addition, the most developed plants from the samples to which compost was added presented self-shading in the evaluated leaves. On the other hand, plants in soil without compost showed smaller leaves and greater exposure to sunlight, which is important to promote the opening of stomata and increase photosynthetic activity (Marenco et al., 2014). Leaves exposed to light may have a higher number of stomata per leaf area when compared to plants subjected to shading. This effect, in addition to greater exposure to sunlight, favours physiological processes, such as the opening of stomata and stimulation of the photosynthetic activity of plants.

\section{Residual effect on soil fertility}

After the lettuce was harvested, soil samples were collected, and the physical-chemical parameters were analysed. The values of $\mathrm{pH}$ in the soils with added compost showed consistency of increase after cultivation, with values of $5.4,6.4,7.0$ and 7.4 for $0,30,60$ and $90 \mathrm{t} \mathrm{ha}^{-1}$, respectively (Figure 3A). These values represented increases of 12.3, 22.8 and $29.8 \%$, when compared to the soil without compost. It
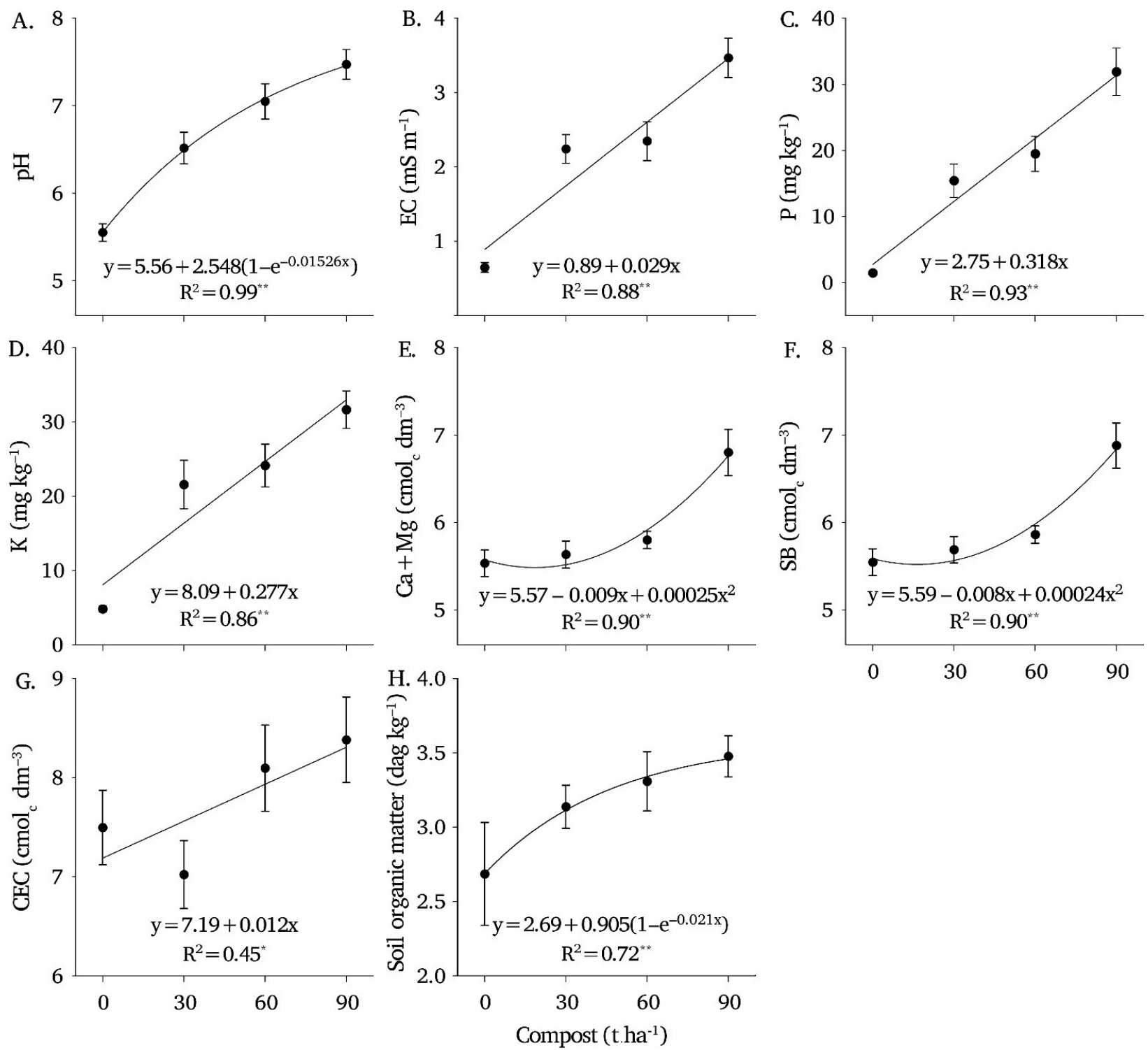

Bars represents standard deviation. *: $p<0.05 ;{ }^{* *}: \mathrm{p}<0.001$

Figure 3. Residual effects of kitchen waste compost on soil fertility parameters after lettuce cultivation. $\mathrm{pH}$ value (A), electrical conductivity "EC" (B), Available phosphorus " $\mathrm{P}$ " (C), Exchangeable potassium "K" (D), Calcium+ Magnesium “Ca+Mg" (E), Sum of bases "SB" $(F)$, cation exchange capacity "CEC" $(G)$ and Soil organic matter $(H)$. 
is important to note that the application of 60 and $90 \mathrm{t} \mathrm{ha}^{-1}$ increased the $\mathrm{pH}$ level to above 7.0. The observed increase in soil $\mathrm{pH}$ was due to the alkaline character of the compost $(\mathrm{pH}=8.0)$, which was applied to an acidic soil $(\mathrm{pH}=5.7)$. The groups of anionic function like carboxyl and hydroxyl (R-COO and $\mathrm{R}^{-} \mathrm{O}^{-}$) present in organic materials adsorb $\mathrm{H}^{+}$from the soil solution, increasing the $\mathrm{pH}$. Also, the addition of basic cations such as $\mathrm{K}, \mathrm{Ca}$, and $\mathrm{Mg}$, as well as the formation of $\mathrm{OH}^{-}$and $\mathrm{HCO}_{3}$, resulting from the mineralization of carbonaceous compounds, contribute to increased $\mathrm{pH}$ in the soil. For most crops this may not be beneficial, as it might reduce the cationic micronutrients and P availability (Lopes \& Guilherme, 2016), promoting nutritional deficiency.

For each $30 \mathrm{t} \mathrm{ha}^{-1}$ of compost applied, the soil CE was increased by $96 \%$, from 0.89 to $3.46 \mathrm{mS} \mathrm{cm}^{-1}$ at doses of 0 and $90 \mathrm{t} \mathrm{ha}^{-1}$, respectively (Figure $3 \mathrm{~B}$ ), probably due the presence of salts in the compost, as previously mentioned. The levels of available $P$ also increased after cultivation with the addition of compost, at the rate of $0.318 \mathrm{mg} \mathrm{kg}^{-1}$ for each ton of compost (Figure 3C). Similarly, the levels of $\mathrm{K}$ enhanced after harvest, at the rate of $0.227 \mathrm{mg} \mathrm{kg}^{-1}$ for each ton of the compost (Figure 3D). Both $\mathrm{P}$ and $\mathrm{K}$ had residual effects well explained by linear models. The behaviour of $\mathrm{Ca}+\mathrm{Mg}$ and SB were better explained by quadratic models (Figure $3 \mathrm{E}$ and $\mathrm{F}$ ) and these variables were about $25 \%$ higher at the dose of $90 \mathrm{t} \mathrm{ha}^{-1}$, when compared to soil without the addition of compost. The soil CEC exhibited a linear residual effect in which each ton of compost resulted in increases of $0.012 \mathrm{cmol}_{\mathrm{c}} \mathrm{dm}^{-3}$ (Figure $3 G)$. The exponential model better described the behaviour of the soil organic matter and increases of 16.0, 24.2 and $29.3 \%$ were observed with the addition of 30,60 and $90 \mathrm{t} \mathrm{ha}^{-1}$ of the compost (Figure $3 \mathrm{H}$ ).

As previously stated, the compost showed $\mathrm{P}, \mathrm{K}, \mathrm{Ca}$, and $\mathrm{Mg}$ in the concentrations of $31.0,3.26 .2$, and $16.6 \mathrm{~g} \mathrm{~kg}^{-1}$, respectively. After harvest, the content of $P$ was 650.1, 750.3, and $1400.1 \%$ higher than the control treatment $\left(0 \mathrm{t} \mathrm{ha}^{-1}\right)$ in the samples that received the doses of 30,60 , and $90 \mathrm{t} \mathrm{ha}^{-1}$, respectively. Increases in $\mathrm{pH}$ and soil organic matter may have contributed to reducing the $\mathrm{P}$ adsorption by Fe and $\mathrm{Al}$ oxides, making it available in the soil solution.

The content of $\mathrm{K}$ with the doses of 30,60 , and $90 \mathrm{t} \mathrm{ha} \mathrm{H}^{-1}$ was $300.4,340.5$ and $520.1 \%$ higher than the samples without added compost, respectively. For $\mathrm{Ca}+\mathrm{Mg}$, a relevant residual effect was observed only for the dose of $90 \mathrm{t} \mathrm{ha}^{-1}$ (19.3\% higher than the soil without compost addition). The maintenance of high CEC, which can be attributed to the preservation of the soil organic matter, as well as the high $\mathrm{pH}$ values, related to the presence of anionic functional groups that consume $\mathrm{H}^{+}$, helped maintain the high levels of basic cations, such as $\mathrm{K}, \mathrm{Ca}$ and $\mathrm{Mg}$.

Soil organic matter was 23.2, 27.4 and $32.7 \%$ higher than the soil without compost addition, for the doses of 30 , 60 , and $90 \mathrm{t} \mathrm{ha}^{-1}$, respectively. Compost application in the soil increases organic matter and improves soil productivity, since this component is the ultimate source of nutrients and microbial activity. The soil organic carbon preservation after compost addition depends on soil mineralogy (Busato et al., 2012). According to these authors, in weathered soils, some organic fractions, such as fulvic acids, are strongly sorbed by oxides due to their large amounts of carboxylic groups, increasing the residence time of these materials in the soil.

The principal components analysis (PCA) showed that principal component 1 (PC1) explains $68.8 \%$ of the total variability (Figure 4 ) and separates the control dose ( $\left.0 \mathrm{t} \mathrm{ha}^{-1}\right)$ from the other compost doses. Thus, in general, the compost application, regardless of the dose, resulted in residual effects for the fertility parameters when compared to the soil without compost. However, the dose of $30 \mathrm{t} \mathrm{ha}^{-1}$ resulted in a little distinct effect from the 60 and $90 \mathrm{t} \mathrm{ha}^{-1}$ doses concerning $\mathrm{PC} 1$. Compost application of up to $60 \mathrm{t} \mathrm{ha}^{-1}$ contributed to the maintenance of high levels of $\mathrm{pH}, \mathrm{EC}, \mathrm{P}, \mathrm{K}, \mathrm{Ca}+\mathrm{Mg}$, SOM and CEC after harvest, which represents an above-average residual effect of the compost on the soil for all doses. The improvement of soil fertility parameters is widespread, because they are interrelated. This improvement translates into increased crop productivity.

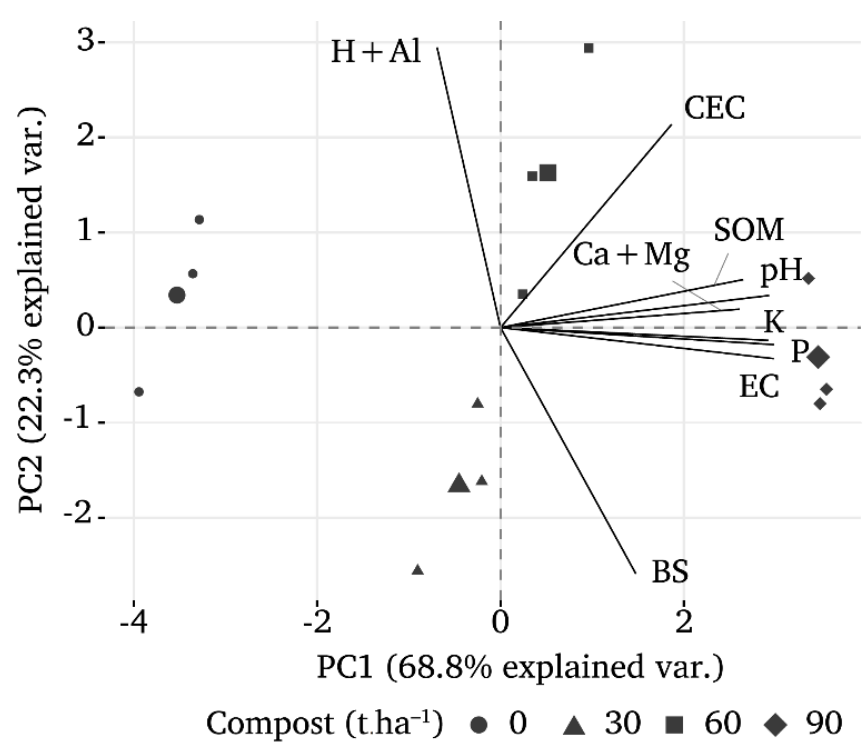

Figure 4. Principal component analysis of fertility parameters in a Latosol under addition of kitchen waste compost and cultivated with lettuce.

\section{Conclusions}

The kitchen waste compost produced by static piles system presented chemical characteristics in accordance with the Brazilian regulation and absence of $E$. coli, but a large $E C$ value was detected. The compost addition reduced the net $\mathrm{CO}_{2}$ assimilation, stomatal conductance and leaf transpiration in lettuce plants, but increased shoot and root dry mass and shoot projection. The compost application resulted in a residual effect on soil fertility, observed by the maintenance of high values of $\mathrm{pH}, \mathrm{K}, \mathrm{Ca}+\mathrm{Mg}, \mathrm{P}, \mathrm{SB}, \mathrm{CEC}$ and soil organic matter after harvest. The kitchen waste compost obtained from static piles is a safe product that enables the recycling of nutrients and organic matter, encouraging the development of lettuce and resulting in a residual effect on the characteristics of soil fertility. 


\section{Ackowledgements}

The authors thank Lucas Moya (Compostar Project ${ }^{\mathrm{TM}}$ ) for providing the compost and the area for this research.

\section{Compliance with Ethical Standards}

Author contributions: Conceptualization: JGB; Data curation: JKMC, ACOS, JF, NMSB, DFSM; Formal analysis: JKMC, DFSM; Methodology: JKMC, ACOS, JF, NMSB, DFSM; Project administration: AMP, JGB; Resources: AMP, JGB; Supervision: AMP; Validation: AMP, JGB; Writing - original draft: JKMC, ACOS, JF, NMSB, DFSM; Writing - review \& editing: AMP, JGB.

Conflict of interest: The authors declared no potential conflicts of interest with respect to the research, authorship, and/or publication of this article.

Financing source: The authors received no financial support for the research, authorship, and/or publication of this article.

\section{Literature Cited}

Arrigoni, J.P.; Paladino, G.; Garibaldi, L.A.; Laos, F. Inside the smallscale composting of kitchen and garden wastes: Thermal performance and stratification effect in vertical compost bins. Waste Management, v.76, n.1, p.284-293, 2018. https://doi. org/10.1016/j.wasman.2018.03.010.

Associação Brasileira de Empresas de Limpeza Pública e Resíduos Especiais - ABRELPE. Organic waste management in Latin America: challenges and advantages of the main treatment options and trends. São Paulo-SP: UN Environment, 2017. 30p. https://abrelpe.org.br/pdfs/publicacoes/report_onu_eng.pdf. 19 Dec. 2019.

Associação Brasileira de Normas Técnicas - ABNT. ABNT NBR 10007: Amostragem de resíduos sólidos. Sampling of solid waste. Rio de Janeiro: ABNT, 2004. 21p.

Barrena, R.; Font, X.; Gabarrell, X.; Sánchez, A. Home composting versus industrial composting: Influence of composting system on compost quality with focus on compost stability. Waste Management, v. 34, n.7, p. 1109-1116, 2014. https://doi. org/10.1016/j.wasman.2014.02.008.

Brasil. Ministério da Agricultura, Pecuária e Abastecimento. Manual de métodos Analíticos oficiais para fertilizantes e corrretivos. Brasília: MAPA, 2014a. 220p.

Brasil. Ministério da Agricultura, Pecuária e Abastecimento. Instrução Normativa $\mathrm{N}^{\circ} 27$, de 05 de junho de 2006. Diário Oficial da União, v., n.110, seção 1, p.15-16, 2006.

Brasil. Ministério da Agricultura, Pecuária e Abastecimento. Instrução Normativa $\mathrm{N}^{\circ} 25$, de 23 de julho de 2009. Estabelece normas sobre as especificações e as garantias, as tolerâncias, o registro, a embalagem e a rotulagem dos fertilizantes orgânicos simples, mistos, compostos, organominerais e biofertilizantes destinados à agricultura. Diário Oficial da União, v.146, n.142, seção 1, p.2024, 2009.
Brasil. Ministério da Agricultura, Pecuária e Abastecimento. Instrução Normativa $\mathrm{N}^{\circ} 17$, de 18 de junho de 2014. Estabelece o Regulamento Técnico para os Sistemas Orgânicos de Produção, bem como as listas de substâncias e práticas permitidas para uso nos Sistemas Orgânicos de Produção. Diário Oficial da União, v.151, n.116, seção 1, p.32-36, 2014b.

Busato, J.G.; Leão, T.P.; Baldotto, M.A.; Canellas, L.P. Organic matter quality and dynamics in tropical soils amended with sugar industry residue. Revista Brasileira Ciência do Solo, v. 36, n. 4, p.1179-1188. 2012. https://doi.org/10.1590/S0100-06832012000400012

Corato U.; Salimbeni, R.; De Pretis, A.; Patruno, L.; Avella, N.; Lacolla, G.; Cucci, G. Microbiota from 'next-generation green compost' improves suppressiveness of composted Municipal-Solid-Waste to soil-borne plant pathogens. Biological Control, v. n.1, p.124:1-17, 2018. https://doi.org/10.1016/j.biocontrol.2018.05.020.

Empresa Brasileira de Pesquisa Agropecuária - Embrapa. Sistema brasileiro de classificação de solos. 3.ed. Brasília: Embrapa, 2013. $353 p$.

Empresa Brasileira de Pesquisa Agropecuária - Embrapa. Manual de métodos de análises de solo. 2.ed. Rio de Janeiro: Embrapa Solos, 2011. 230p. (Embrapa Solos. Documentos, 132). https:// www.infoteca.cnptia.embrapa.br/bitstream/doc/990374/1/ ManualdeMtodosdeAnilisedeSolo.pdf. 07 Dec. 2020.

Food and Agriculture Organization - FAO. World fertilizer trends and outlook to 2020. Rome: Food and Agriculture Organization of United Nations, 2017. 27p. http://www.fao.org/3/a-i6895e.pdf, 17 Dec. 2020

Han, Z.; Ma, H.; Shi, G.; He, L.; Wei, L.; Shi, Q. A review of groundwater contamination near municipal solid waste landfill sites in China. Science of the Total Environment, v.569-570, n.1 p. 1255-1264 2016. https://doi.org/10.1016/j.scitotenv.2016.06.201.

Hoornweg, D.; Bhada-Tata, P. What a Waste: A global review of solid waste management. Washington: World Bank. 2012. 98p. (World Bank. Urban development series. Knowledge papers, 15). http:// hdl.handle.net/10986/17388. 07 Dec. 2020.

Lopes, A.S.; Guilherme, L.R.G. A career perspective on soil management in the Cerrado region of Brazil. In: Sparks, D.L. (Ed.). Advances in agronomy. v.137. London: Academic Press, 2016. Chap 1, p.1-72. https://doi.org/10.1016/bs.agron.2015.12.004.

Manyapu, V.; Mandpe, A.; Kumar, S. Synergistic effect of fly ash in in-vessel composting of biomass and kitchen waste. Bioresource Technology, v.251, n.1, p.114-120, 2018. https://doi.org/10.1016/j. biortech.2017.12.039.

Marenco, R.A.; Nascimento, H.C.S.; Magalhães, N.S. Stomatal conductance in Amazonian tree saplings in response to variations in the physical environment. Photosynthetica, v.52, n.1, p493-500, 2014. https://doi.org/10.1007/s11099-014-0056-3.

Park, S.-H.; Lee, B.-R.; La, V.H.; Al Mamun, M.; Bae, D.-W.; Kim, T.-H. Characterization of salicylic acid- and abscisic acid-mediated photosynthesis, $\mathrm{Ca}^{2+}$ and $\mathrm{H}_{2} \mathrm{O}_{2}$ accumulation in two distinct phases of drought stress intensity in Brassica napus. Environmental and Experimental Botany, v.186, 104434, 2021. https://doi. org/10.1016/j.envexpbot.2021.104434.

Roomi S.; Masi, A.; Conselvan, G.B.; Trevisan, S.; Quaggiotti, S.; Pivato, M.; Arrigoni, G.; Yasmin, T.; Carletti, P. Protein profiling of Arabidopsis roots treated with humic substances: insights into the metabolic and interactome networks. Frontier in Plant Science, v.9, n.12, p.1812, 2018. https://doi.org/10.3389/fpls.2018.01812. 
Sakarika, M.; Spiller, M.; Baetens, R.; Donies, G.; Vanderstuyf, J.; Vinck, K.; Vrancken, K.C.; Barel, G.; Du Bois, E.; Vlaeminck, S.E. Proof of concept of high-rate decentralized pre-composting of kitchen waste: Optimizing design and operation of a novel drum reactor. Waste Management, v.91, n.1, p.20-32, 2019. https:// doi.org/10.1016/j.wasman.2019.04.049.

Siles-Castellano, A.B.; López, M.J.; López-González, A.; SuárezEstrella, F.; Jurado, M.M.; Estrella-González, M.J.; Moreno, J. Comparative analysis of phytotoxicity and compost quality in industrial composting facilities processing different organic wastes. Journal of Cleaner Production, v. 252, n.10, 19820, 2020. https://doi.org/10.1016/j.jclepro.2019.119820.
Stewart-Wade, S.M. Efficacy of organic amendments used in containerized plant production: Part 1 - Compost-based amendments. Scientia Horticulturae, v. 266, n.10, e108856, 2020. https://doi.org/10.1016/j.scienta.2019.108856.

Testani, E.; Montemurro, F.; Ciaccia, C.; Diacono, M. Agroecological practices for organic lettuce: effects on yield, nitrogen status and nitrogen utilisation efficiency. Biological Agriculture and Horticulture, v.36, n.1, p. 84-95, 2019. https://doi.org/10.1080/0 1448765.2019.1689531.

Yang, F.; Li, Y.; Han, Y.; Qian, W.; Li, G.; Luo, W. Performance of mature compost to control gaseous emissions in kitchen waste composting. Science of the Total Environment, v.667, n.20, p.262269, 2019. https://doi.org/10.1016/j.scitotenv.2018.12.030. 